\title{
Implementation of Holistic Education in Shaping Akhlakul Karimah at Madrasah Aliyah Al-Munawwarah Guppi in Parepare
}

\author{
Hasan Basri Rasima \\ Muhammadiyah University of Parepare \\ hb881988@gmail.com
}

\begin{abstract}
This research raises the issue of the application of character-based holistic education in shaping Akhlakul Karimah viewed from the perspective of Islamic education. Holistic education provides an opportunity to explore the talents present in learners both in body and soul, character education emphasizes the importance of wholeness between knowledge, attitudes, and behavior of individuals to be able to live and work together, whether in the family, society, nationand country. The shaping of Akhlakul Karimah from the perspective of Islamic education wants the seriousness of parents, teachers, and the community in shaping the character of the child from an early age that includes the cognitive (knowledge) affective (attitude) and psychomotor aspects in supporting the establishment of Akhlakul Karimah in the learners. The study was done by qualitative methods on collecting data. As an effort to give birth to the younger generation of Muslims who are cautious to Allah and to martyrdom then the existing Islamic education must be reconstructed including the curriculum used. The Islamic education curriculum should prioritize the noble values of a religion and culture in its implementation for the realization of character education in Indonesia.
\end{abstract}

Keywords: Character, Holistic, Islamic Education, Akhlakul Karimah

\section{INTRODUCTION}

The important issues that are currently sticking to the surface in the world of education, especially in Indonesia are character education. The application of characterbased holistic education in shaping Akhlakul Karimahis a form of response to moral decadence in building social reality with consequences on the depth of the nation in various lines of life.The even moral collapse has forced this nation to its knees to the values of dehumanization in the structural and cultural circles. The character-based of holistic education is an education that aims to give students the freedom to develop themselves not only intellectually, but also facilitate the development of the soul and body as a whole so as to create a strong Indonesian human that can lift the nation's dignity [1]. This model of education is an education that is explicitly aimed at developing all human dimensions, namely academic cognitive, emotional, social, spiritual, motor, and creativity aspects. By the holistic learning, it can be developed the critical thinking ability, creativity, and reflective [2]. This is because learning activities focus more on students so that the functions and roles of students are seen [3].

The term holistic is a term derived from English from the root word "whole" which means a whole. With the taking of basic meaning like this, according to Husein Heriyanto, the holistic paradigm can be interpreted as a thorough perspective in perceiving reality. A holistic view means looking more at the whole aspect than the section, systematic, integrated, complex, dynamic, nonmechanical, and nonlinear [4]. In addition, the term holistic is also derived from the word heal (healing) and health (health).

This indicates that holistic thinking means healthy thinking. The domain of education, holistic education is an educational method that builds humanity as a whole and whole by developing all human potential that includes social potential-emotional, intellectual potential, moral potential or character, creativity, and spiritual [5]. The purpose of holistic education is to form a holistic man. Holistic man is a human being who is able to develop all the potential that is in him. The potential that exists in man includes academic potential, physical potential, social potential, creative potential, potential emotions and spiritual potential [6]

Humans who are able to develop their full potential are holistic human beings, ie true human learners who always realize that they are part of a vast system of life, so always want to contribute positively to the environment. The purpose of education in Indonesia as stipulated in the Law of the Republic of Indonesia number 20 of 2003 is to form a holistic and characteristic human. Human holistic and character is a social capital for the development of a nation. Holistic education is not limited to three Bloomian realms but demands to pay attention to all the needs and potentials of learners, whether in the intellectual, emotional, physical, artistic, creative, and spiritual aspects [7]. The choice of this holistic education paradigm can certainly be viewed in line with the worldview of Islamic education. According to the documents of the Ministry of National Education, character education is defined as value education, character education, moral education, character education, which aims to develop the ability of learners 
to make good decisions, maintain good, and realize the good in daily life with wholeheartedly [8],[9].

Therefore, the development of value that leads to the formation of the character of the nation obtained through various channels, levels, and types of education, will encourage them to become members of the community, children of the nation, and citizens who have a superior personality as expected in national education goals. Until this day, curricular efforts have been made to make education more meaningful to individuals who not only give knowledge but also touch affective and cognitive levels through subjects of Religious Education, Civic Education, Indonesian Language Education and Physical Education. However, it must be acknowledged because of the rapidly changing age conditions, these efforts have not been able to accommodate the dynamic and adaptive character development of those changes [10], [11].

Just recently, it is known madrasah aliyah students progressively have declined in terms of their character development. So the character-based education process is expected to increase the activity of students in following the series of learning activities and later teachers can formulate a step that can increase the passion of students to learn. The curriculum which used is "character-based integrated curriculum" an integrated curriculum that "touches" all aspects of the child's needs. An associated curriculum not fragmented and can reflect on dimensions, skills, by displaying interesting and contextual themes. Existing areas of development in madrasah aliyah courses developed in life skills education concepts related to personal and social education, thinking / cognitive development, character development and motor perception development can also be well plunged when the subject matter is designed through integrated and holistic learning (holistic) [12].

\section{METHOD}

This research belongs to qualitative research category. This study is conducted tracing the data about the application of character-based holistic education in shaping Akhlakul Karimah to students at the Madrasah Aliyah Al-Munawwarah Guppi in ParepareCity by investigating a symptom in a real-life setting. This strategy may include quantitative evidence based on previous sources and developments of theoretical propositions.

The design of this research is cross-sectional study. The informants of this study are the students of Madrasah Aliyah Al-Munawwarah Guppi in Parepare City, South Sulawesi. This research was conducted on all students in Madrasah Aliyah Al-Munawwarah with the total number of learners is about 200.

Data collection techniques in this study are divided into interviews and observations on learners, as well as directed discussions (FGD), and in-depth interviews with the students and teachers involved in the study.

The research data was collected using an ordinal scale and calculated using percentage to facilitate comparison, then categorized to be good, less and just follow the normative distribution, that is: 1) $\operatorname{good}(\geq 80 \%), 2$ ) enough $(60-80 \%)$, and 3$)$ less $(<60 \%)$. Meanwhile, the data are intervals and ratios such as data in children after treatment or after the study. For quantitative data collected in this study, the process is using the average value of successful research on children.

\section{RESULT}

To form the students in a holistic manner is to develop the physical, emotional, social, creative, spiritual and intellectual aspects of the students optimally. In addition to shaping human lifelong learners (true learners) by applying several strategies, such as a) applying learning methods that involve the active participation of learners, that is methods that can improve student motivation because all dimensions of humans are actively involved with given concrete, meaningful, and relevant subject matter in the context of their life (student active learning, contextual learning, inquiry-based learning, integrated learning); b) creating a conducive learning community so that children can learn effectively in an atmosphere that provides a sense of security, respect, no threat, and encouragement; c) providing character education explicitly, systematically and continuously by involving aspects of knowing the good, the good, and the good acting; d) teaching methods that pay attention to the uniqueness of each child, namely applying a curriculum that involves also 9 aspects of human intelligence; e) all of the above approaches apply the principles of Developmentally Appropriate Practices which based on Islamic perspectives.

Regarding the methodology of character education, if returning to the concept of Islam, to form the character of the cognitive aspect, methods that can be used are advice, stories, lectures, and methods of dialogue. To form the aspect of feelings in character education, the method that can be used is the method of parables (amtsal) and methods tarhib and targhib. The character education in the aspects of deeds can be used method of habituation (habituation) and exemplary (uswah/qudwah). Meanwhile, Ratna Megawangi (in Masnur Muslich), describes the need to apply the $4 \mathrm{M}$ method in Character Education, which is knowing, loving, wanting, and doing good simultaneously and continuously. Masnur further reveals that this method shows that the character is something that is done on the basis of intact consciousness, while the whole awareness is a conscious, beloved, and desirable thing. From this whole consciousness then action can be produced in full. Donni A. Koesoema, as in Masnur, proposed five methods of Character Education (the application in educational institutions), which teach, model, priority, priority praxis, and reflection. The development of Character Education is more specifically should also pay attention to the educational environment. This means that the context of formal and informal education is clearly different. More specifically, Nurul Zuriah tries to formulate the development of Character Education in a formal 
education. He said that the values that can be developed in schools are religious, social, gender, justice.

Madrasah Aliyah Al-Munawwarah Guppi in Parepare City can be known as a madrassa that has an Islamic concept and in every district in Southern Sulawesi already has madrasah aliyah. What makes this MA should have a better educational order is the condition of students who are currently do not have good behavior and there are even stealing, fighting between students can be found even almost every week there are students who fight, get drunk, and who worse is the teacher there has lost its dignity because it is not respected at all. It is hoped that the application of character-based holistic education in shaping Akhlakul Karimah to Madrasah Aliyah Al-Munawwarah Guppi students can change the output of the students at Madrasah Aliyah AlMunawwarah Guppi.

Implementing character-based holistic education in shaping Akhlakul Karimahtowards the students of Madrasah Aliyah Al-Munawwarah Guppi the model of character-based of holistic education curriculum in Madrasah Aliyah Al-Munawwarah Guppi is using a combination of education offices and curriculum from own schools that include self-development, activities habituation, exemplary activities, activities of Nationalism and Patriotism, students' creative week, as well as outdoor learning and training. The application of education in shaping Akhlakul Karimah in Indonesia Heritage Foundation has been called the 9 pillars of character, while in Madrasah Aliyah Al-Munawwarah Guppi the formation of morals still in general. Thus, the character-based holistic education curriculum model in madrasah Aliyah Al-Munawwarah Guppi has not been maximized, because there is no character-based education curriculum in particular. However, the curriculum drawn up by schools is approaching the character-based education curriculum.

\section{CONCLUSION}

The statements in this study can be concluded that: first, holistic education is an educational philosophy that departs from the idea that an individual can essentially discover the identity, meaning and purpose of life through its relationship with society, the natural environment, and spiritual values. Historically, holistic education is not really a new thing. Holistic education is a combination of intellectual, emotional and religious. If it is well developed, it will form a "holistic" soul, which reflects the identity/character or superior character. Holistic education that develops all the intellectual, spiritual, physical, and aesthetic potentials must be put forward in schools to produce the young generation of the nation that has meaning in life. Implementation of holistic education has actually been developed in the world of education in Indonesia since before independence, but now it is even more forgotten.

Secondly, the purpose of holistic education is to help develop the potential of individuals in a more pleasurable and stimulating learning environment, democracy and humanism through experience in interacting with their environment. Through holistic education, learners are expected to be (learning to be) themselves.

Third, Islamic education basically corresponds to the purpose of character education which emphasizes the importance of unity between knowledge, attitude, and behavior.It's just that the education of Islam in its implementation has not been able to make it happen. This is due to the weak awareness of parents, teachers, and the community in shaping the character of children's education from an early age.The change of curriculum has not been able yet to find the right formulation so that the impressions just change the cover and abort the obligation.Not to mention the government's attention to the world of education is still halfhearted, it is evident that there are still many schools that do not meet the standards, the allocation of inadequate educational funds and misdirected.

\section{REFERENCES}

[1] M. Nurul Haerani and E. Ahmad, "Pembangunan Modal Insan Holistik Pelajar Menerusi Aktiviti Kokurikulum Politeknik," Semin. Penyelid. Pendidik. Kebangs., 2013.

[2] Mahdum, Wan Hasmah Wan Mamat, and Zulfahmi, "Pendidikan holistik tantangan dan masa depan," in Pendidikan holistik tantangan dan masa depan, 2014.

[3] Fatimah Saleh, Khadijah Zon, and Zurida Ismail, "Kurikulum Pendidikan Awal: Ke Arah Pendidikan Holistik," Asia Pacific J. Educ. Educ., 1993.

[4] M. Zainuddin, "PARADIGMA PENDIDIKAN ISLAM HOLISTIK," ULUMUNA, 2011.

[5] A. Khodori, "Kepemimpinan Pentaksiran Holistik Memacu Modal Insan Kreatif dan Inovatif.," in Kolokium Pengurusan Pentaksiran Berasaskan Sekolah Tahun 2012, 2012.

[6] M. Latifah and N. Hernawati, "Dampak pendidikan holistik pada pembentukan karakter dan kecerdasan majemuk anak usia prasekolah," Ilmu Kel. dan Konsum., 2009.

[7] R. Zetty Nurzuliana, A. R. Siti Rashidah, M. R. Ahmad Shafiq, S. Norshilawani, and I. Zanaton, "Pendidikan Holistik Di Maahad Tahfiz Sains Negeri Selangor," Pros. Semin. PISH 2017, 2017.

[8] B. Maunah, "Implementasi Pendidikan Karakter dalam Pembentukan Kepribadian Holistik Siswa," J. Pendidik. Karakter, 2015.

[9] N. I. M. Taib, Z. Mahamod, A. R. Haron, and R. Makmun, "Kebolehpercayaan pemeriksaan karangan secara holistik berdasarkan jantina dan pengalaman dalam kalangan guru bahasa melayu sekolah rendah," J. Pendidik. Bhs. Melayu, 2012.

[10] H.Widyastono, "Muatan pendidikan holistik dalam kurikulum pendidikan dasar dan menengah," $J$. Pendidik. dan Kebud., 2012.

[11] A.Fauziah, "Sekolah Holistik : Pendidikan Karakter Ala Ihf," Pros. Semin. Nas. Psikol. Islam., 2012.

[12] Zetty Nurzuliana Rashed and Ab Halim Tamuri, "Kepentingan Integrasi Ilmu Naqli \& Ilmu Aqli dalam Pengajaran Pendidikan Islam," E-Jurnal Pendidik., 2015. 